\title{
Ejournalism: Production, Communication, Interaction and Research Opportunities for Reporters
}

\author{
Alan Knight \\ Central Queensland University, North Rockhampton, Australia
}

a.knight@cqu.edu.au

\section{Abstract}

The Internet is shaping the ways journalists communicate, construct their stories, publish their material and interact with their audiences. Journalism produced for text, audio and television is increasing digitised; converging on the Internet to create a new hybrid professional practice, eJournalism. This paper considers how traditional forms of advanced reporting, such as investigative journalism, may be enhanced by internet technologies.

Keywords: eJournalism, journalism, internet, multimedia, investigative

\section{Introduction}

Multimedia storytelling uses some combination of text, still photos, animated, graphics, video and audio, presented in a nonlinear format in which all of the information in the elements are non-redundant - a very different form of storytelling. It's a two-way communications system: people can search for information. They send their own text, photos, graphics, video clips and audio to comment on stories or provide additional information. (J.Stephens:2002)

The Internet is shaping the ways journalists communicate, construct their stories, publish their material and interact with their audiences. Journalism produced for text, audio and television is increasing digitised; converging on the Internet to create a new hybrid professional practice; eJournalism.

Time remains a critical factor in the creation of quality journalism. Reporters can be expected to continue to strive to beat deadlines and competitors, allowing little margin for reflection. The web however, presents journalists with new opportunities to offer more than mere reviews of official media releases.

\section{The "Reality" of Journalism}

And what were they covering these journalists? What was in the centre of the page?

Mostly theatre. And because of pressures of television, they were mostly matinee performances, designed to catch the six o'clock news. The theatre had gone on tour. The reviewers were still reviewing - noting good performances and gaffes. The difference was that this show [the election] had a reality check at the end of it.

Material published as part of these proceedings, either on-line or in print, is copyrighted by Informing Science. Permission to make digital or paper copy of part or all of these works for personal or classroom use is granted without fee provided that the copies are not made or distributed for profit or commercial advantage AND that copies 1) bear this notice in full and 2) give the full citation on the first page. It is permissible to abstract these works so long as credit is given. To copy in all other cases or to republish or to post on a server or to redistribute to lists requires specific permission from the publisher at
Margaret Simons; writing about reporters covering the Australian national elections. (Simons: 1999 p110)

Journalists are presumed to play a critical role in the democratic political process. Yet politics can become a scripted event where spectacle can overwhelm substance. Spin merchants may seek to create a series of television friendly vignettes, where 
Ejournalism

critical questions are discouraged and performances are enhanced. Journalists can then become seen as minor players in the same unfolding drama they are attempting to critique.

This blurring of such roles is evident both in domestic political reporting and the coverage of international events. During the Hong Kong handover, more than five thousand members of the international press were screened by government public relations controllers, security checked, balloted to even enter events, and mostly denied the opportunity to ask questions; giving them little alternative to a "press release reality". A former news editor of the Far Eastern Economic Review suggested that such reporters might as well have been in South America when it came to the quality of eye witness coverage of the handover.(Knight/Nakano: 1999. p162.)

But should this process necessarily reduce reporters to being little more than reviewers? Should journalism practitioners explore new methods of news gathering; ones which are beyond the reach of the spin merchants seeking to dominate reportage?

The Internet may provide alternatives here for pressed reporters. The computers and modems which they increasingly use to file their stories from field, might just as easily be used for news gathering. Online investigative reporting could then offer a more substantial solution to contrived press release realities.

\section{Ejournalism: Communications}

In 1870, the London Times correspondent, William Russell found his essays on the Franco Prussian war scooped by less well known competitors who cabled the news back home:

In the past, only news 'flashes' had been transmitted by wire. Now an army of pushing, vulgar, uncouth and alarmingly effective American correspondents had taken the field, who regarded the mails as a tool of the stone age, and relied almost exclusively upon the telegraph to file their despatches. (Hastings: 1995. xxiv)

Internet has replaced "cable" by delivering Email, voice and video links; allowing contemporary reporters to maintain global links with their editors and participate in editorial conferences where stories are discussed. Text, vision and audio items are created in digitised files which may be easily transmitted to base by telephone, satellite link or radio broadcast. The huge and cumbrous portable live broadcast facilities used by CNN to cover the Gulf war are already being replaced by laptops, modems and satellite phones. During the Hong Kong handover in 1997, photographers were filing from the China border even as the People's army rolled in:

There was a Swedish guy who had a very tight deadline who was using a sat [satellite] phone to send his material directly back [to Sweden]. He plugged his digital camera into his laptop, added the captions and then dialled his newspaper direct. (Tatlow:1997)

\section{Ejournalism: Production}

Modern news writing devolved from a clipped pyramidal style developed for economic transmission of stories from remote locations via the telegraph. That style influenced the choice journalists made when they constructed stories; eg. The quote sought in interviews, the illustrations selected and the headlines. These usually unstated production requirements became a learned part of a pervasive newsroom culture.

Journalists have been quick to adopt new communications technology but may be slower to abandon old practices. Early radio news reports consisted of an announcer reading newspaper stories on air. Early television bulletins seemed to be little more than radio with pictures. New styles evolved to meet the potentials of the newer media. Agence France Press Webmaster, David Sharp said the internet was already affecting the way AFP journalists wrote their stories:

The worldwide web creates the possibility for hyper linking therefore there is a possibility to create much richer story structures which in itself can also create problems because it's 
very easy to build structures which are too complicated for people to follow. But for general reading of stories there is definitely a trend towards brevity because it's well known for example that the average person reading text from a screen will read about $25 \%$ slower than the same person reading the same information from a printed page. People generally do not want to scroll so there's another reason for brevity. There tends to be a trend towards using more subtitles as in bulleted lists, getting use to the idea that on the Internet people can and do begin reading a story at any point. Therefore you need to structure stories in such a way that different parts of it are comprehensible in themselves. So I think it is changing the way people write (Sharp, 1999).

Ejournalism transcends and incorporates the one dimensional stories of earlier media. Stories on the Internet will be multi-faceted and the journalists who produce them will need to be multiskilled: able to create logical and clear textual accounts, link information, gather audios and take videos and photo images. They will be able to incorporate them all on a single or series of websites. Linear concepts of news can as a result be expected to transform into multi layered reports reflecting the wider choice of informations.

\section{Ejournalism: Distribution:}

The Internet allows the polished digitised product to be published globally; wherever computers are linked to the telecommunications grid. Deadlines can become meaningless as material can be filed quickly and maintained on the web indefinitely. Censorship has been made more difficult as web publishers proliferate. Journalist organisations such as the British based Association of Investigative Journalists established websites to create an outlet for reports mainstream conventional media might seem reluctant to publish:

The decline in investigative journalism, and individual outlets for such serious reporting, is a pernicious form of implied censorship; the presence of light entertainment or consumer journalism in place of, say, a programme such as World in Action means that the issues that would otherwise have been presented to the public in such programming are effectively barred from public consumption. Part of our task is to challenge such censorship in all its forms. (http://www.aij-uk.com/policy.htm)

However wider distribution can be at the cost of easy validation, undercutting notions of news as authenticated and credible versions of events. According to newsagency Internet editor, Sharp, journalists have an expanded role, bringing meaning to the mass of information on the web:

People are getting used to the notion now that if they have a question they can find the answer to it very quickly and if they don't there's something wrong. Whereas in the past the consumer basically had to accept what they got out of the print newspaper which was a limited amount of news. The concept of an infinite news hole which the web provides, is a very attractive concept. But it is also a very dangerous one, because human beings can only absorb no more than a given amount of information at any given time. Therefore the problem that arises with the Web is no longer a problem of accessing information but the problem of having too much information. Therefore it has to be organised, structured, and made meaningful in ways that weren't necessary before. (Sharp: 1999)

In short, the web provides a continuing role for journalists acting as mediators of information; professional writers who assemble identifiable cultural packages for mass consumption. 


\section{Ejournalism: Interaction}

Communications were revolutionised in 1876, when Alexander Graham Bell received a patent for the telephone. With this new medium, two way, immediate communication over long distances was possible for the first time.

The telephone changed the way people conducted business, relayed important information, and, as the technology became more affordable, socialised with one another. As teenagers once aggravated their parents by hours talking on the telephone, today they can fulfil the same urges on the Internet -in chat rooms and on the Net. (Moschovitis et al:1999 p 6)

The net offers audiences more variable interactions than those previously offered by edited newspapers' letter pages or the theatrical radio talk back programs. Moderated bulletin boards or email discussion groups can allow informed interaction with an informed audience. Foreign correspondents regularly participate in lists including H-Asia (historians, researchers, Orientalists) and Listserv SEASIA (journalists, Asia scholars). Such lists can provide contact with identified, credible sources with access to significant background material. In recent years, issues including Taiwan's elections, Nato's bombing of a Chinese embassy and the Asian economic downturn have all been the subject of erudite discussion on these lists.

Open chat programs and discussion groups can also sometimes be a source for stories. Ejournalist, Matt Drudge, broke the news about President Clinton's affair with Monica Lewinsky with the help of tip offs from the net. Drudge saw his reporting as reporting stories ignored by the insider culture of the Washington press corps. The News Editor of Business Week magazine dismissed Drudge's often unsourced work as "suspect in the eyes of most journalists". But Drudge told the National Press Club in Washington that he received six million visitors a month to his website which began as an email mailing list:

We have entered an era vibrating with the din of small voices. Every citizen can be a reporter, can take on the powers that be. The difference between the Internet, television and radio, magazines, newspapers is the two-way communication. The Net gives as much voice to a 13-year-old computer geek like me as to a CEO or speaker of the House. We all become equal. And you would be amazed what the ordinary guy knows. (Drudge: 1998)

However, not all information is created equally. Subsequent lawsuits against Drudge would indicate that tips gathered from chat groups or anonymous informants must be verified and investigated by journalists. Drudge's early success may be more attributed his daring to use to the power of publication on the internet, rather than the quality of Drudge's research.

\section{Ejournalism: Research and Reporting}

A study of foreign corespondents operating in Australia, conducted by the author, indicated rapidly increasing use of the Internet as a source of information. Indeed, these experienced, computer literate journalists rated web sites as their most useful source of information. ABC (national) Radio was rated as the equally most useful source. ABC (national) Television was rated third most useful. Quality newspapers, the Sydney Morning Herald (rated equal first), The Australian Financial Review (rated second) and the Australian (rated fourth) continued to be a major, if not the most important source, for correspondents. Correspondents noted the importance of newspaper linked websites as accessible, updated sources of "branded' information.

Primary sources; public servants (rated fifth), non government organisations (rated $6^{\text {th }}$ ), corporations (rated $7^{\text {th }}$ ) and politicians (rated $8^{\text {th }}$ ) rated highly but less so than the leading news outlets. The search engine, Yahoo (rated ${ }^{\text {th }}$ ), was seen as more useful than Diplomats (rated 10 ${ }^{\text {th }}$ ), the domestic Australian newsagency, Australian Associated Press (rated $11^{\text {th }}$ ), the Age news paper (rated $12^{\text {th }}$ ), government newsletters (rated $13^{\text {th }}$ ) CNN (rated $14^{\text {th }}$ ) or the BBC World Service (rated $15^{\text {th }}$ ). 
This result, combined with the reliance on web sites, indicated the growing importance of the interactive Internet as a source of information for journalists. It suggested that correspondents were becoming less reliant on news agencies, the hard wired, international news distributors. This result may pose questions about the longer term future of these wire services which retail news and offer media release distribution to other news organisations. (Knight:2001)

The Internet with its access to original, identifiable sources, online news papers and media release services was preferred as a source to the news agencies which have dominated international news for more than a century.

Seventeen years ago, a study by Andrew Szende found that ASEAN journalists saw that the four big international news agencies (Reuters, Associated Press, UPI and AFP) as being among the most useful six sources. The two Hong Kong based news paper magazines, the Asian Wall street Journal, and the Far Eastern Economic Review were respectively second and fourth highest. (Szende 1986 pp 19/20.)

In a study by the author of Australian journalists in Cambodia in 1993, correspondents rated diplomats as most useful, followed by the weekly magazine, the Far Eastern Economic Review, BBC Radio, the Thai newspapers and Radio Australia. Two of the big four international news agencies, Reuters and Agence France Press (AFP) were also in the top ten, reflecting their extensive use by the Australian correspondents' employers. The Asian Wall Street Journal and BBC Television were also rated highly. (Knight 2001 pp99/100.)

However more recently, in the United States, the Annual Survey of Media in the Wired World, noted that Internet usage by American journalists was rapidly rising, with journalists using the net for article research, increasing from 66 percent in 1995 to 92percent in 2000. 73 percent used the net to find media releases:

Ninety eight percent of the journalists responding this year say that they're online at least once a day to check email and spend 15 hours a week reading and sending email. ...Email now matches the phone as a first choice method of working with sources, and there's no question that journalists are engaging in more dialogue with readers via email. (Middleberg, Ross. 2000 p 1)

But does the net offer more than a steady source of news releases or at worst, the opportunity to compare of plagiarise other's work?

\section{Investigative Reporting}

Daily reporters are deluged with transitory events which sometimes obscure the larger issues; the gaffes, media releases, staged photo opportunties and hot house intrigues of parliamentary politics. Pressed by deadlines, hemmed by the size of the news hole and isolated from research facilities, daily journalists are frequently forced to ignore the stories behind the news. Yet journalists, empowered by internet research, may be able to reach further.

Democracy is founded on a number of principles, including the accountability of elected representatives and civil servants to the people. Ideally, a host of mechanisms should guarantee this, but even the best systems may be abused. [Simply reporting what one has been told by those in authority may obscure rather than reveal the truth.] Experience shows that when wrongdoing does take place, investigative journalists are among those best placed to expose it and ensure that justice is done.

The international anti censorship organisation Article XIX (Article 19: 2000)

Journalism could be seen as non fiction writing (news) which relies on identifiable sources. Investigative Journalism might be defined as finding important news someone does not want the public to know. Journalists, as Article 19 suggested, have professional and ethical responsibilities to look beyond what they have been told by those in authority. Investigative Journalists can as a result be seen as custodians of the 
Ejournalism

public conscience. According to Ettema and Glasser, this does not mean that investigative journalists should decide how everyone else should behave:

They are not the guardians of some superior moral knowledge. Rather these journalists have the means to report and disseminate stories that can engage the public's sense of right and wrong. These journalists are, in other words, custodians of exactly what we imagine our consciences to be: a morally engaged voice.(Ettema/Glasser: 1998. P 4)

Investigative journalism combines basic journalism reporting skills with more advanced research methods. Original research was seen as the distinguishing feature of investigative reporting:

It is not a summary or piecing together of others' findings and data, but original research carried out by reporters using often the rawest of material. It can be extensive interviewing, or matching and comparing facts and figures. In many cases, the fruits, and originality, come in discovering patterns and connections in the information that no one has observed before. (Randall: 1996. pp78/79)

Randall wrote that investigative reports often resulted from a "suspicion of wrongdoing". An investigative reporter would be required to engage in a prolonged inquiry, compiling a research dossier, from which a story or stories might be written. Such inquiries would require reporters and editors to manage time and resources, so that results might be maximised, he said.

\section{Investigative Reporting on the Net}

Interviews, documents, surveillance and surveys are the tools of the investigative reporter. The reporter learns which to use at a certain time, like a golfer who knows which club to use under different conditions as he or she progresses through a course. The best investigators during the course of their investigation may draw on all of the tools at one time or another. (Gaines: 1998. p17)

The Internet offers investigative journalists new tools for reporting; qualified access to global communities of interests which may provide alternate sources to those in authority. In doing so, it presents opportunities and problems for investigative reporters. Meanwhile, it impacts on production processes with radio, television and text journalism practices converging through digitisation on the internet; towards a new hybrid profession, ejournalism. With faster computers, newer compressed programs and wider band widths, internet publications will rapidly offer more sophisticated, interactive variants of the older media.

Such investigative reporting need not be expensive or beyond the reach or ordinary journalists. But it does require greater commitment than daily journalism. Daily news reporting can be relatively quick, clean and have clear objectives. Investigative journalists must transmit complex information to a very wide public; applying illustrations, audio grabs, computer generated graphics, and library footage appropriate to their selected medium.

\section{Truth Seeking on the Web}

Investigative reporters, in one way or another, affirm their commitment to the idea that they can and must find out what really happened. But like historians and judges, they must rely on documents, records, artifacts, and memories in the effort to do so. Under these conditions the process for establishing the truth cannot entail the examination of what really happened, followed by the production of the single correct account that corresponds to what really happened. Rather, the process must entail the location and examination of existing accounts and the production of still another account that can be accepted as authoritative.

Ettema and Glasser in Custodians of Conscience (New York. Columbia University Press. 1998. p137) 
Investigative journalism may seek to serve the public interest by telling stories of outrageous private misbehaviour by public officials. Journalists may not be secular saints. However, moral outrage should not justify questionable behaviour by reporters. There are sound practical reasons for this approach. If they are to have any credibility, journalists who seek to expose wrong doing must themselves be seen to understand ethics. Public relations practitioners may try to discredit reporters by diverting the debate to attacks on the way the story was produced. Politicians may use the privilege of parliament to defame their critics.

Clearly sourcing is critical to journalism which assumes to be investigative reporting. Investigative stories are constructed on a series of sources. A misquotation can bring the whole structure down, leaving the journalist, editor and publisher vulnerable to legal action. Under these circumstances, sourcing must be accurate, contextual and systematic. The web offers thousands of accessible sources for journalists. Avenues of online investigations might include:

- Officilal Government Sources

- Individuals

- NGO's

- Businesses

- Data Bases

\section{Official Government Sources}

Free political journalism is an essential part of democracy, a safeguard against totalitarianism. In every Parliament House, a paradox may be observed: living side by side are politicians who try to keep much of what they say and do, and political journalists whose aim is to penetrate the secrecy which and officials try to maintain. The outcome of this constant struggle is a compromise. The politicians andofficials are not able to suppress all that they wish to keep secret. The journalists are unable to discover all thatshould, in the public interest, be publicised.

Age Political reporter, John Bennets wrting in the 1965 cadet journalists guide, The Journalists Craft (Sydney: Angus\&Robertson. 1965 pp 157)

Governments everywhere have gone online, and more data is being daily. Government web sites include speeches, policy documents, briefing materials, department structures and responsibilities, telephone indexes and biographies. Political statements can be crosse referenced and contextualised by computer. Political reporters who still need to rely on media releases can down load them for confirmation and possible inclusion. Most media releases are also archived on the web, allowing statements and policies to be checked against earlier pronouncements. The ABC's former chief political reporter, Matt Peacock said that computers made it easier to search for relevant documents, which might have otherwise ended "in the bin".

...A big difference now with the Web is that you can go back and people are much more on the record, particularly governments. So that you do a search on a particular subject and you'll be able to unearth the press releases that the Minister, or whoever else it is, said a year or two years or three years ago on that same subject. So they're a little bit more accountable and it's a bit easier now to search for that. But certainly the key to what could be called investigative journalism but could also be called just good, professional journalism, is having time. (Peacock:2000) 


\section{Individuals}

There are two questions that investigative researchers should ask themselves before conducting research on an individual: first is there a substantial case for undertaking research on that particular individual, or is the research motivated by nothing more than mere curiosity? And the second question should be: is this the right individual to be researching, or is there another individual (or others) relevant to this piece of investigative research who should be scrutinised?

David Northmore in Lifting the Lid (London. Wellington House. 1996.pp 77)

Individuals provide colour and context of investigative stories. Electoral rolls, digitised telephone indexes professional associations and even university records can add to the public knowledge of individuals' private activities. Information can be drawn from hotlinked sites or any of the many professional information gathering agencies.

EG Profnet Global (http://www.profnet.com/america.html) can supply reporters queries about individuals with information from universities, corporations, government agencies, NGO's and PR agencies. The group also maintains an international "experts" data base.

Email interviews can be directed through lists such as the Address Directory of Politicians of the world which claims addresses for the monarchs, presidents and prime ministers of 196 countries. (http://www.trytel.com/ aberdeent)

\section{Databases}

Data bases are now used in several ways by most US dailies. For most, the old paper "morgue" of clipped stories has been replaced by a computerised library in which the paper's own stories are stocked. Second, commerical data bases are routinely searched by reporters seeking various kinds of background information. Third, some newspapers construct their own databases on specialised topics...Finally the analysis of the computerised records of government agencies has become increasingly common.

Margaret De Fleur. Computer Assisted Investigative Reporting. 1997. Erlbaum Associates. New Jersey. p41.

Database analysis, or Computer Assisted Reporting, can provide statistics an overview to background a story, indicating how important it might be in the general state of things. The challenge for investigative reporters is to find accurate and appropriate data and use it in ways that a general audience can understand and relate to.

Computer Assisted Reporting takes records from government agencies, making use of federal or state versions of freedom of information legislation, deciphering coding documentation, transferring compactly stored data into software (spreadsheets or statistical packages) and using statistical procedures to analyze the information to reveal trends. (Semonche. Ed. 1993)

CAR usually requires training in spreadsheet construction and journalists applying this technique frequently need the support of specialist researchers and librarians.

CAR works on deadline if you remember computers don't have to drive the story. Computers can enhance the story. View the computer as another tool --one that help you find information or do quick analysis on deadline. (Roberts: 1999)

\section{Conclusion}

Online journalism is emerging as a multidimensional convergence of existing journalism practices. The Internet has become a new source for investigative reporters, allowing non linear alternatives in journal- 
ism style. It offers opportunities for independent publishing. The net allows journalists to communicate, produce and research more effectively. But in doing so it eclipses earlier notions that journalists can be defined as mereley television, text or radio reporters employed by mainstream mass media.

\section{References}

\section{Books}

De Fleur, Margaret.. Computer Assisted Investigative Reporting. 1997. Erlbaum Associates. New Jersey.

Ettema, James, Glasser, Theodore. Custodians of Conscience: Investigative Journalism and Public Virtue. Columbia University Press. New York. 1998.

Gaines, William Investigative Reporting for Print and Broadcast Nelson-Hall Chicago. 1998.

Hastings, Max. "Introduction", Hudson, Roger. (ed) William Russell: Special Correspondent of The Times. Folio Society. London. 1995.

Kingston, Margot. Off the Rails: the Pauline Hanson trip. Allen\&Unwin. Sydney, 1999.

Knight, Alan and Nakano, Yoshiko, Reporting Hong Kong: the Foreign Press and the Handover. Curzon. London. 1999.

Knight, Alan. Reporting the Orient: Australian correspondents in Cambodia Xlibris, 2001.

Moschovitis et al. A History of the Internet. ABC-CLO Books Santa Barbara. 1999.

Randall, David The Universal Journalist . Pluto Press. London. 1996.

Simons, Margaret. Fit to Print: Inside the Canberra Press Gallery. UNSW Press. Sydney. 1999.

Walraff, Gunther. The Undesirable Journalist, Pluto Press, London, 1977.

Weinberg, Steve. The Reporter's Handbook: An investigators's Guide to Documents and Techniques. St Martin's Press. New York. 1996.

Winkler, Matthew and Wilson, David, The Bloomberg Way: a guide for reporters and editors. Bloomberg News. 1998.

\section{Articles/Papers}

Drudge, Matt. 2.6.1998."Anyone with a Modem can report on the world." National Press Club Address, Washington. Hitp.//Www.frontpagemag.com/archives/dirudgetdrudge.hmm

Hong Kong Journalists Association. "HKJA launches campaign for open government" Hong Kong. 8.2.98.

Knight, Alan. "The Future of the Media in Hong Kong and China: the responsibilities of journalism educators under one country two systems" The East West Centre Conference for Journalists. Hong Kong Foreign Correspondents Club. 15.11.97.

Knight Alan. "The Cambodia Referendum-A Case Study Methodology” Unpublished Phd Thesis1995.

Middleberg, Don. Ross, Stephen. Survey of media in the Wired World. Columbia University Graduate School of Journalism.New York 2000.

Mitchell, Chris "Why the southern media got One Nation so wrong", The Brisbane Institute, May 25, 1999.

Roberts. J " Quick CAR; you can do it in an hour...if you are prepared" 1999 Freedom Forum Technology Conference for Educators. February 28. March 3, 1999.

Stevens, Jane. "Backpack Journalism Is Here to Stay" 2002 Online Journalism Review. University of Southern California. http://www.ojr.org/ojr/trends/1016158044.php

Szende, Andrew. From Torrent to Trickle: Managing the Flow of News in Southeast Asia, 1986.

\section{Interviews}

Hoyt, Shaun. Researcher, journalist, PR. Washington (email) May 2000.

Garret, Kirsten. Executive Producer, Background Briefing. Sydney. January 2000.

Sharp, David. Sydney. November 1999. 
Ejournalism

Toohey, Brian. Business writer and columnist. Sydney/Rockhampton. March 2000.

Peacock, Matthew. ABC Naqtional Political reporter Sydney/Rockhampton. April 2000.

Wilkinson, Marian. Author, investigative journalist. Sydney/Rockhampton. March 2000.

\section{Websites:}

Address Directory of Politicians of the World: http://www.trytel.com/ aberdeen/

Agence France Press: nttp://www.afp.com/english/

Article 19: http://www.article19.org

Association of Investigative Journalists: htp./Www.aij-uk.com/

Centre for Investigative Reporters: http://www.muckraker.org/

Dateline Hong Kong:http://www.geocities.com/Athens/Forum/2365/

Drudge Report: http:/twww.drudgereport.com/

International Consortium of Investigative Journalists: hएp:/Www.icij.org/

Investigative Reporters and Editors: hup:/twww.ire.org

Philippine Center [sic] for Investigative Journalism: http://www.pcij.org.ph/

\section{Biography}

Professor Alan Knight is a journalism educator with a specialist interest in Online Journalism, Foreign Correspondence and Asian Studies. The foundation Chair of Journalism and Media Studies at Central Queensland University, Dr Knight is an electronic media journalist who has worked as a reporter and editor for the Australian Broadcasting Corporation, Radio Television Hong Kong and other media outlets. A former Director of the Australian Centre for Independent Journalism, he is an Honorary Research Fellow at the Centre for Asian Studies at Hong Kong University. He is co-author of Reporting Hong Kong: the foreign press and the handover (Curzon Press: London, 1999).

http://www.ejournalism.au.com 